GEOLOGICAL SURVEY CIRCULAR 479

\title{
BERYLLIUM DEPOSITS OF THE WESTERN SEWARD PENINSULA, ALASKA
}


BERYLLIUM DEPOSITS OF THE WESTERN

SEWARD PENINSULA, ALASKA

By C. L. Sainsbury

Washington 1963 
United States Department of the Interior STEWART L. UDALL, SECretary

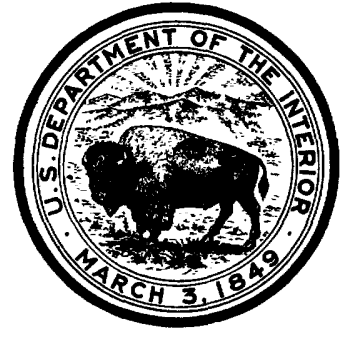

Geological Survey

THOMAS B. NOLAN, DIRECTOR

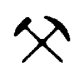

Free on application to the U.S. Geological Survey, Washington 25, D. C. 


\section{CONTENTS}

\begin{tabular}{|c|c|c|c|}
\hline \multicolumn{2}{|c|}{ age } & \multicolumn{2}{|l|}{ 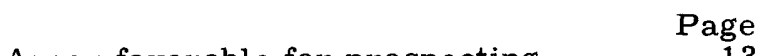 } \\
\hline Abstract & 1 & Areas favorable for prospecting & \\
\hline Introduction & 1 & Lost River-Brooks Mountain area ... & 13 \\
\hline Location and accessibility & 1 & King River & \\
\hline eologic setting & 2 & Area east of Tin Creek...... & \\
\hline Beryllium deposits & 3 & Ear Mountain & \\
\hline Known lodes & 4 & Cape Mountain & \\
\hline Camp Creek-Lost River mine ........ & 4 & Potato Mountain & \\
\hline Lost River Valley & 8 & Black Mountain $\ldots \ldots \ldots$ & \\
\hline Rapid River & 9 & Suggestions for prospecting & \\
\hline Tin Creek & 9 & Selected bibliography & \\
\hline
\end{tabular}

\section{ILLUSTRATIONS}

Figure 1. Map of the western Seward Peninsula, Alaska, showing areas of known and potential beryllium deposits .

2. Geologic map of the Lost River-Tin Creek area, Seward Peninsula, Alaska ...... 6

3. Geologic map of the Rapid River area, Seward Peninsula, Alaska _.. . . . . . . 10

4. Geologic map of the Tin Creek area, Seward Peninsula, Alaska . . . . . . . . . . 12

5. Map showing location and beryllium content of sediment samples, Lost River area, Seward Peninsula, Alaska _.

6. Geologic map of Ear Mountain, Seward Peninsula, Alaska _... . . . . . . . . . 14

7. Geologic map of Cape Mountain, Seward Peninsula, Alaska _. . . . . . . . . . 15

8. Geologic map of Black Mountain area, Seward Peninsula, Alaska .......... 16

\section{TABLES}

Table 1. Beryllium minerals in ores from the Lost River area

2. Beryllium content of nonberyllium minerals, Lost River area, Alaska

3. Quantitative spectrographic analyses of bulk samples of beryllium ores, Lost

River area, Alaska . .

4. Beryllium and fluorine content of ores from Camp Creek. . . . . . . . . . . 7

5. Beryllium and fluorine content of ores from Lost River Valley . . . . . . . . 8

6. Beryllium and fluorine content of ores from Rapid River . . . .

7. Beryllium content of ores from Tin Creek 


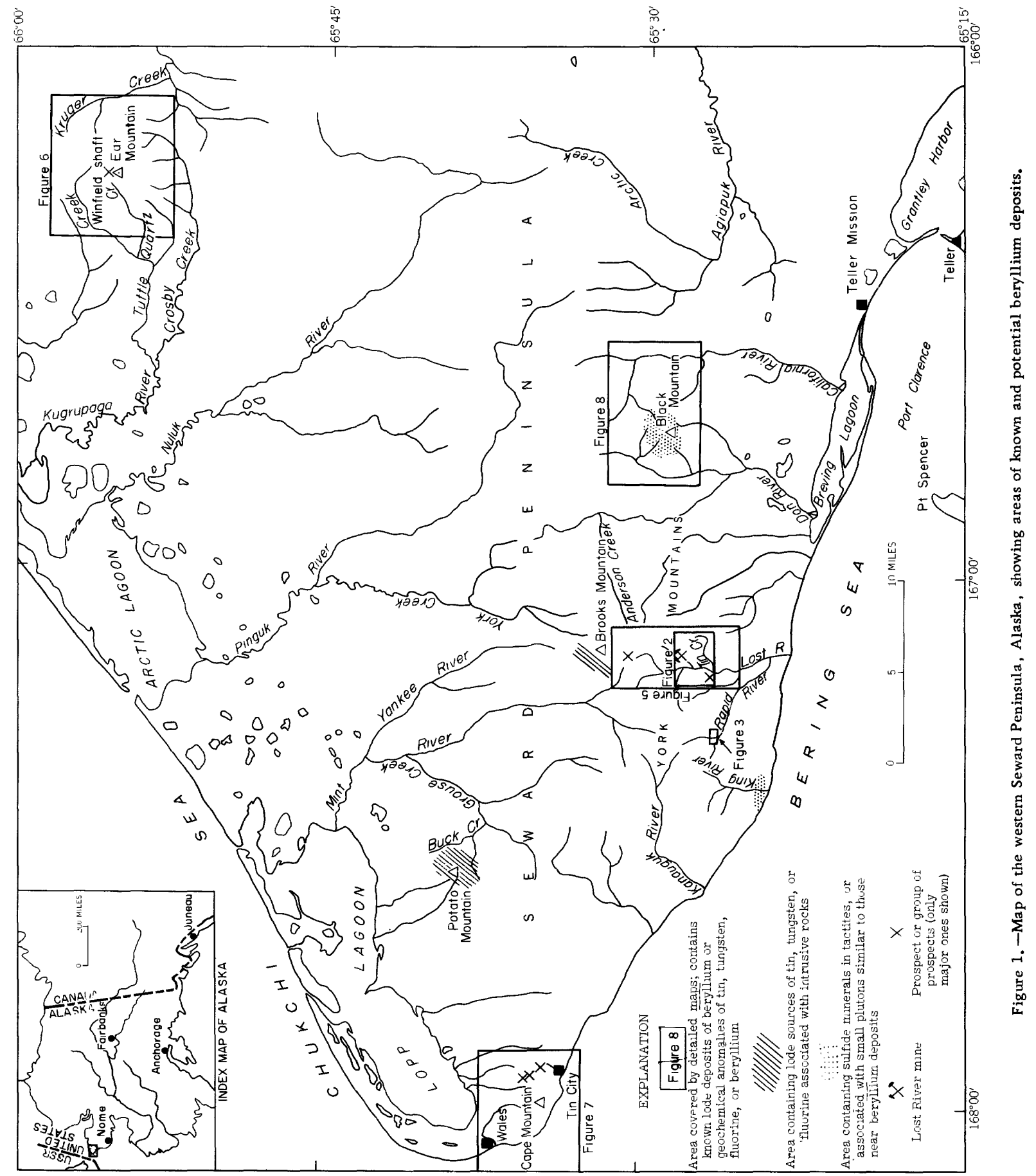




\title{
Beryllium Deposits of the Western Seward Peninsula, Alaska
}

\author{
By C. L. Sainsbury
}

\begin{abstract}
Deposits of beryllium ore in the Lost River area of the western Seward Peninsula, Alaska, consist of replacement veins, pipes, and stringer lodes in limestone in a zone about 7 miles long and 2 to 3 miles wide which is faulted and intruded by dikes and stocks.

The ores are remarkably alike and typically consist of the following minerals, in percent: fluorite, 45-65; diaspore, $5-10$; tourmaline, $0-10$; chrysoberyl, 3-10; white mica, $0-5$; small amounts of hematite, sulfide minerals, manganese oxide, other beryllium minerals; and traces of minerals not yet identified. The ores generally are cut by late veinlets which are of the same mineralogy as the groundmass ore, or which consist of fluorite, white mica, and euclase. The ores are fine grained, and many of the individnal mineral grains, except fluorite, are less than $1 \mathrm{~mm}$ in size. The beryllium content of bulk samples of ore ranges from 0.11 to 0.54 percent $(0.31$ to 1.50 percent $\mathrm{BeO})$. High-grade nodules, composed principally of chrysoberyl, diaspore, fluorite, and mica, contain as much as 6 percent $\mathrm{BeO}$.
\end{abstract}

Geochemical reconnaissance has disclosed other areas of anomalous beryllium in stream sediments elsewhere on the Seward Peninsula, generally around biotite granites that have them associated with tin deposits; additional exploration probably will disclose other deposits.

\section{INTRODUCTION}

Nonpegmatitic beryllium deposits of a type not previously known in North America were found in several localities in the western part of the Seward Peninsula, Alaska, during geologic mapping by the U.S. Geological Survey in 1961 and 1962, and anomalous geochemical concentrations elsewhere suggest that other comparable deposits may be found. The area under discussion is shown in figure 1.

Tin deposits have long been known in the western Seward Peninsual (see "Selected bibliography"), and beryllium minerals and beryllium-bearing skarns have been known in the Lost River area since 1942. In 1960, W. R. Griffitts of the U.S. Geological Survey noted that reports published by the U.S. Bureau of Mines indicated that beryllium was present in anomalous amounts in placer concentrates elsewhere on the Seward Peninsula, and this observation led to the geochemical reconnais sance which resulted in the discovery of the deposits described below.

The writer gratefully acknowledges support received from many sources. A beryllium detector built by John Ohm of the Geological Survey, under the guidance of W. W. Vaughn, aided mapping of the Rapid River deposits and the estimation of grade of ores. Donald Grybeck and T. E. Smith assisted in the field investigations, and G. D. Eberlein helped in sample collection. Many Alaskan residents and organizations freely provided material support and aided the author in many ways.

\section{LOCATION AND ACCESSIBILITY}

Nome is the nearest large town, Teller, Teller Mission, and Wales are villages within the area (fig. 1). Gasoline, foodstuffs, and common supplies are available at Nome and Teller, although the selection is limited prior to the arrival of the first ship in Nome in June or July. Three established airlines serve the western Seward Peninsula from Nome and Teller, and supplies can be landed at numerous small unmarked airstrips as well as at larger airfields. Heavy supplies and equipment must be lightered ashore or landed from barges which serve the coastal areas from Nome and from Teller, which is the nearest deepwater harbor. A mining access road is under construction from Teller to Lost River, and a gravelled road is under construction between Nome and Teller. A good gravel road leads from the beach at the mouth of Lost River to an airstrip which can accomodate C -46 cargo aircraft, and thence to the mine. 
The various reports listed in the bibliography, especially Lorain and others (1958), provide more detailed information on access, climate, and operating problems.

\section{GEOLOGIC SETTING}

The principal rocks of the western Seward Peninsula are the slate of the York region, a thick unit of highly deformed and slightly metamorphosed shale, gravwacke, and schist ose argillaceous limestone of pre-Early Ordovician age (Steidtmann and Cathcart, 1922), and the Port Clarence Limestone, a thick sequence of limestone, argillaceous limestone, and dolomitic limestone which overlies the slate unconformably. The Port Clarence Limestone has yielded fossils ranging in age from lowest Early Ordovician to Late Silurian. Recent geologic mapping has disclosed that in the York Mountains a shaly limestone, generally schistose and cut by numerous quartz-calcite veins, lies between the slate of the York region and rocks generally referred to the Port Clarence Limestone; it too is probably pre-Early Ordovician in age. Numerous small bodies of basic rocks were intruded into the slate in pre-Early Or dovician time, and one sheared gabbroic dike has intruded the schistose limestone. The Port Clarence Limestone and older rocks have been intruded by granites, rhyolites, and quartz diabase dikes. A long period of erosion and deformation probably intervened between deposition of the slate of the York region and the Port Clarence Limestone.

Within the area containing the known beryllium deposits, the Port Clarence Limestone is predominantly Early Ordovician in age, although some Middle Ordovician rocks are known.

Sections of the limestone 3,000 feet thick have been measured, and it is probably much thicker in places.

In Late Cretaceous time, plutons and dikes of medium - to coarse-grained biotite granite and rhyolite porphyry intruded the slate of the York region and Port Clarence Limestone. Subsequently, quartz diabase dikes were injected along some of the fractures of the same systems occupied by earlier dikes. The granite forms bosses which are exposed at Cape Mountain, Ear Mountain, Brooks Mountain, Tin Creek, and Black Mountain (figs. 1, 4, 7, and 8), and which underlie the Lost River mine area, and probably the Potato Mountain area, at shallow depth. The youngest igneous rocks, of Quaternary and Recent ages, are dikes and flows of olivine basalt, in part scoriaceous.

Coarse cobble and pebble conglomerates occur on the York Terrace, which appears to be an elevated marine platform along the southern part of the York Mountains (Steidt mann and Cathcart, 1922, p. 16). The conglomerates are probably not more than 150 feet thick, and crop out in isolated patches having areas of generally less than a square mile.

Because the slate of the York region generally surrounds the younger Port Clarence Limestone in the western and northern Seward Peninsula, earlier workers interpreted the structure as a great north-trending faulted syncline (Steidtmann and Cathcart, 1922, p. 32). Recent detailed geologic mapping has shown that in the York Mountains numerous low-angle thrust faults cut the limestone and locally cut the slate. Over an area about 30 miles in an east-west direction and 20 miles in a north-south direction, the Port Clarence Limestone dips generally north at angles from a few degrees to almost vertical. This attitude prevails to the west end of the York Mountains where the contact with the slate strikes almost north. This is believed to be strong evidence that the Port Clarence is in thrust contact with the slate. The constant northward dips of the limestone beds, even where thrust sheets of different facies of limestone of approximately equivalent age overlie each other, constitute the most notable structural feature in the York Mountains and probably explain the fact that thrusting was not previously recognized.

Following the thrusting, normal faults of three distinct systems occurred in the limestones. The strongest and most persistent system strikes generally N. $70-85^{\circ} \mathrm{E}$. and is characterized by faults which are downthrown to the south, the second set strikes N. 30-50 W., and the third set strikes a few degrees west of north. These fractures guided the emplacement of the dikes and provided the main channels for ore deposition. Most of the known beryllium deposits are alined along a zone about 7 miles long and 2 to 3 miles wide which trends N. $80-85^{\circ} \mathrm{E}$. from Rapid River on the west to east of Tin Creek (fig. 1) and which contains numerous dikes and faults 
as well as several plutons. This zone is a large-scale feature which is evident only on geologic maps covering areas larger than those that accompany this report, although individual maps (figs. 2, 3,4) depict fractures and dikes which are part of the large zone. A few beryllium deposits occur as veins along fractures formed radially around the granite on Tin Creek (fig. 4), and in innumerable small fractures near or above buried plutons.

\section{BERYLLIUM DEPOSITS}

The beryllium-bearing deposits found to date lie along a zone about 7 miles long by 2 to 3 miles wide that extends $\mathrm{N} .80^{\circ} \mathrm{E}$. across the drainage basin of Lost River. Within this zone are four distinct mineralized areas, each about 4,000 feet long by 1,000 feet wide; how ever, only a small part of the bedrock in these areas is ore.

Except for minor amounts of beryllium in tactite (skarn) near granite contacts, the beryllium deposits are replacement lodes in limestone and consist of veins, pipes, and ir regular stringer lodes. Veins range from a few hundred to 2,000 feet in length and from less than 2 to 12 feet in thickness. Some stringer lodes cover areas of several thousand square feet. In any one area, veins, pipes, and stringer lodes generally occur together.

The beryllium ores are nondescript rocks which differ but slightly in appearance from the argillaceous limestones in which they commonly occur. In hand specimen, the ores are noticeably heavy, for their specific gravity ranges from 2.98 to 3.5 , substantially above that of the limestone (2.60-2.65). On weathered surfaces, the ores often have a distinct purplish or faint greenish caste, and the purplish coloration especially contrasts with most of the surrounding limestone. Faint bands, generally a few millimeters wide, are oriented subparallel to the veins. Late veinlets as much as a few millimeters thick, generally white, cut the ores and stand out on weathered surfaces. These veinlets both parallel and cut across the faint banding. A gray-white lichen grows preferentially on some ores and aids in their recognition. Where found in argillaceous limestone, the ore customarily weathers into blocks substantially larger than the limestone because of its greater coherence and its resistance to frost action and to solution.
Although the ores vary somewhat from deposit to deposit, they all consist basically of fluorite, diaspore, chrysoberyl, white mica, and tourmaline, together with minor amounts of other beryllium minerals, sulfide minerals, hematite, manganese minerals, and other minerals as yet unidentified.

The modal composition of typical ore, as determined by a study of thin sections, is, in percent: fluorite, 45-65; diaspore, 5-15; tourmaline, 0-10; chrysoberyl, 3-10; white mica, $0-5$; small amounts of hematite, arsenopyrite, euclase, phenakite(?), milarite(?), bertrandite(?), and pyrite; and minute amounts of other minerals. The fluorite occurs as clear ovoid grains as much as $2 \mathrm{~mm}$ in diameter and as intimate intergrowths with other minerals as small as a few microns in diameter. The space between the larger fluorite grains is filled with a very fine grained intergrowth consisting of fluorite, diaspore, and chrysoberyl, and, less commonly, tourmaline and mica. The chrysoberyl is commonly on the borders of the fluorite. Some chrysoberyl occurs as festoonlike bands composed of grains a few microns across. Other festoonlike bands are composed of fluorite and almost cryptocrystalline mica(?). Occasionally grains of chrysoberyl, phenakite(?), bertrandite(?), and milarite(?), generally less than $0.1 \mathrm{~mm}$ in size, occur in fractures in the larger fluorite grains. Younger veins cutting the ores may be similar in mineralogy to the groundmass but of noticeably coarser texture, or they may consist of mica, fluorite, ellclase, bertrandite(?), milarite(?), and hematite. Where mica predominates over fluorite in the late veinlets, cassiterite and hematite occur, as well as an unidentified sulfide mineral resembling tetrahedrite. The euclase in the late veinlets forms lustrous pearly-white flakes as much as a centimeter in diameter. Locally, as in the Lost River valley, late veinlets of purplish fluorite and white mica as much as 2 inches thick cut the ores. Some specimens of ore from Tin Creek are encrusted with white mica in tabular growths. Unusual nodules as much as a foot in diameter occur in the Camp Creek ores; a typical nodule consists of a central core of very fine grained chrysoberyl, diaspore, and minor white mica surrounded by a rim as much as an inch thick of gray to faintly purplish fluorite. Abundant white mica and diaspore occur between the rim and core, and a black manganese oxide coats fractures in the nodules. These nodules contain as much as 6 percent 
Table 1.-Beryilium minerals in ores from the Lost River area

\begin{tabular}{|c|c|c|c|}
\hline Material & Formula & $\begin{array}{c}\mathrm{BeO}^{1} \\
\text { (percent) }\end{array}$ & Occurrence \\
\hline Chrysoberyl ${ }^{2}$ & $\mathrm{BeAl}_{2} \mathrm{O}_{4} \ldots$ & $16.9-19.7$ & Common in almost all samples. \\
\hline Euclase_. & $\mathrm{BeAlSiO}_{4}(\mathrm{OH})$ & 16.9 & $\begin{array}{l}\text { In late veinlets; associated with white } \\
\text { mica; common. }\end{array}$ \\
\hline Bertrandite & $\mathrm{Be}_{4} \mathrm{Si}_{2} \mathrm{O}_{7}(\mathrm{OH})_{2} \ldots$ & $39.6-42.6$ & $\begin{array}{l}\text { In late veinlets; associated with mica; } \\
\text { uncommon. }\end{array}$ \\
\hline Beryl_. & $\mathrm{Be}_{3} \mathrm{Al}_{2}\left(\mathrm{SiO}_{3}\right) 6 \ldots$ & $10.0-14.0$ & $\begin{array}{l}\text { In quartz-muscovite veins at Lost River } \\
\text { mine; absent or rare in fluorite ores. }\end{array}$ \\
\hline Phenakite & & $44.0-45.6$ & $\begin{array}{l}\text { In altered granite at Lost River mine; } \\
\text { rare or absent in fluorite ores. }\end{array}$ \\
\hline Milarite & $\mathrm{K}_{2} \mathrm{Ca}_{4} \mathrm{Be}_{4} \mathrm{Al}_{2} \mathrm{Si}_{24} \mathrm{O}_{60} \cdot \mathrm{H}_{2} \mathrm{O}_{-}$ & 5.0 & $\begin{array}{l}\text { Enclosed in fluorite in some ores from } \\
\text { Rapid River; rare. }\end{array}$ \\
\hline
\end{tabular}

${ }^{1}$ Usual $\mathrm{BeO}$ content of similar minerals as reported by Warner and others, (1959).

${ }^{2}$ Pure chrysoberyl separated from ore from Rapid River and analyzed spectrographically by John Hamilton of the U.S. Geological Survey contains 7 percent Be (19.4 percent BeO).

BeO. Hematite and a black manganese mineral provisionally identified as todorokite are conspicuous in some ores from Camp Creek and Tin Creek. A summary of information on the beryllium minerals identified to date is given in table 1. All except milarite are confirmed by $\mathrm{X}$-ray diffraction.

The beryllium in the ores is believed to be present principally in definite beryllium minerals, although small amounts are in minerals that normally do not contain beryllium, especially in tourmaline. Preliminary spectrographic analyses of virtually pure fractions of other minerals separated from the ores gave the results reported in table 2 .

Because many specimens of ore containing as much as 6 percent $\mathrm{BeO}$ contain no tourmaline, it is assumed that the beryllium in

Table 2.-Beryllium content in percent of nonberylliurn minerals, Lost River area, Alaska

[Analysts: Fred Waring and John Hamilton, U.S. Geological Survey]

Mineral

$\mathrm{Be} \quad \mathrm{BeO}$

\begin{tabular}{|c|c|c|}
\hline Mica_.......... & 0.01 & 0.03 \\
\hline Fluorite_._. & .01 & .03 \\
\hline Tourmaline...... & $.30 ; 1.0$ & $.8 ; 2.8$ \\
\hline Diaspore $^{1}$ - & .02 & .06 (estimated) \\
\hline
\end{tabular}

${ }^{1}$ Identified by Fred H. Hildebrand, U.S. Geological Survey, by use of the powder camera. tourmaline constitutes only a minor percentage of the total beryllium in bulk ore samples. In one specimen tested, about 85 percent of the contained beryllium was recovered as chrysoberyl.

Spectrographic analyses of bulk ores from several of the deposits show small amounts of other common elements, as shown in table 3 . No attempt has yet been made to account for the distribution of these elements, but their presence may influence the choice of recovery processes and metallurgy of the ores.

\section{KNOWN LODES}

The four areas where deposits have been found are described below in the order of their assumed potential.

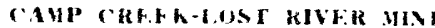

The largest known veins, as well as the largest potential reserves of beryllium, are near the Lost River mine (fig. 2). The deposits consist of (1) a discontinuous vein or stringer lode. trending eastward for about 5,000 feet along the south slope of Camp Creek from a point near the junction of Camp Creek and Cassiterite Creek and (2) of innumerable smaller bodies in and near the Lost River mine. Neither (1) nor (2) has yet been studied in detail by the Geological Survey.

The ore in Camp Creek trends approximately east-west in the western 1,000 feet 


\begin{tabular}{|c|c|c|}
\hline \multirow{2}{*}{\multicolumn{2}{|c|}{ 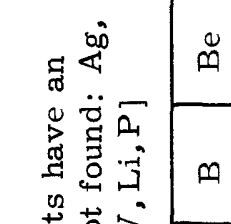 }} & 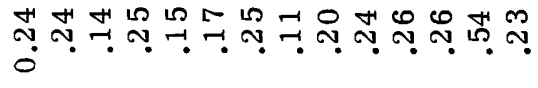 \\
\hline & & 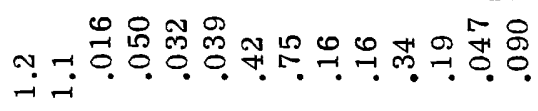 \\
\hline 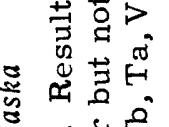 & $\tilde{\oplus}$ & 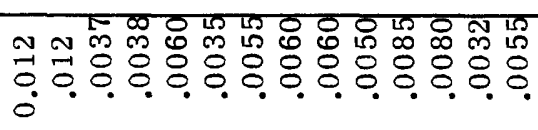 \\
\hline 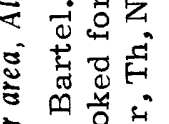 & $\dot{m}$ & 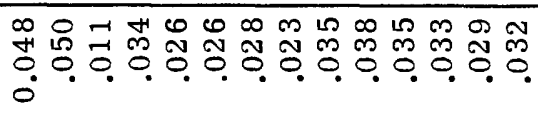 \\
\hline 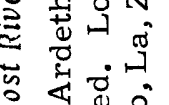 & $\sum_{i=1}^{\infty}$ & 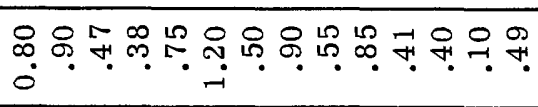 \\
\hline 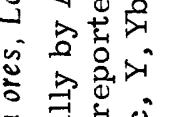 & $\ddot{E-1}$ & 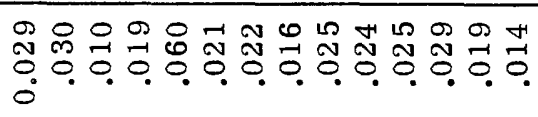 \\
\hline 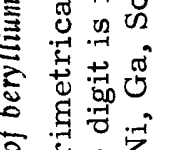 & $>$ & 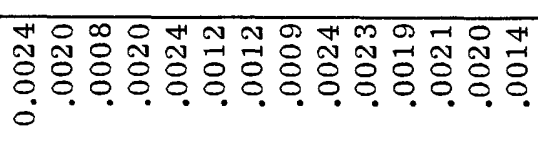 \\
\hline 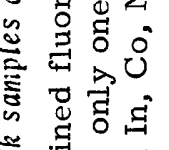 & $\ddot{U}$ & 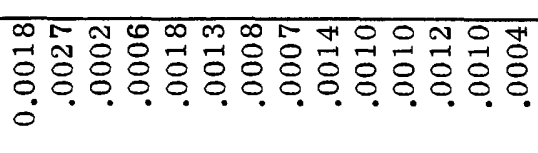 \\
\hline 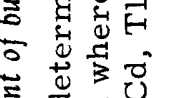 & 诖 & 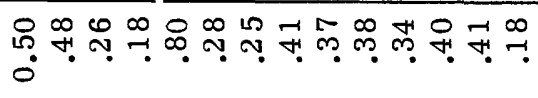 \\
\hline g & 童 & 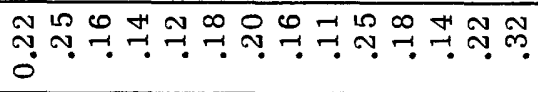 \\
\hline 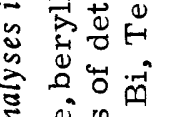 & $\hat{D_{1}}$ & 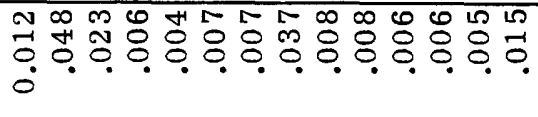 \\
\hline 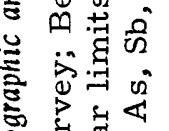 & घี & 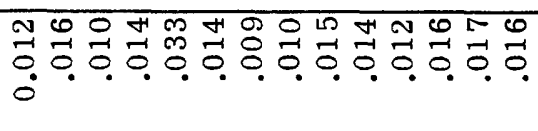 \\
\hline 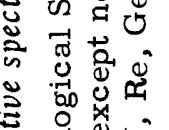 & $U^{3}$ & 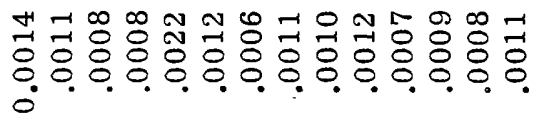 \\
\hline 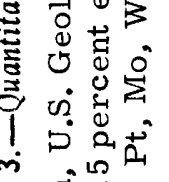 & \begin{tabular}{l}
$\dot{0}$ \\
$\dot{0}$ \\
$\dot{\pi}$ \\
\multirow{2}{*}{}
\end{tabular} & 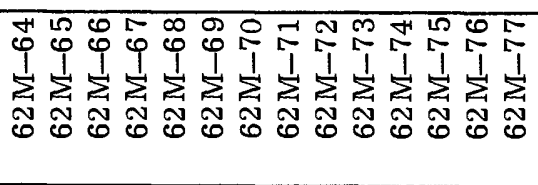 \\
\hline 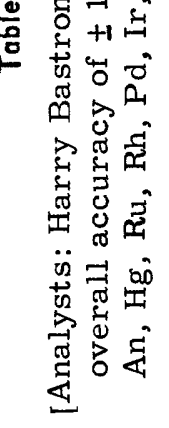 & 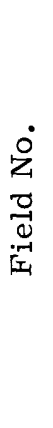 & 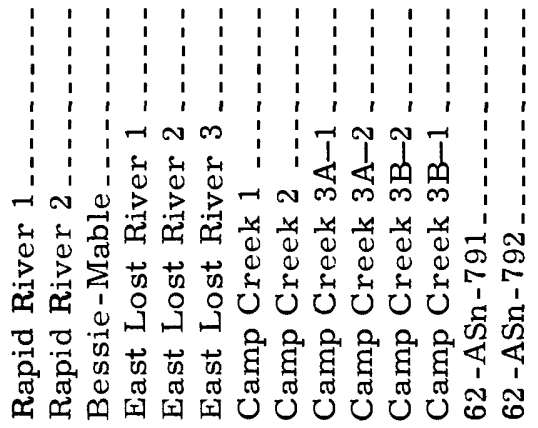 \\
\hline
\end{tabular}




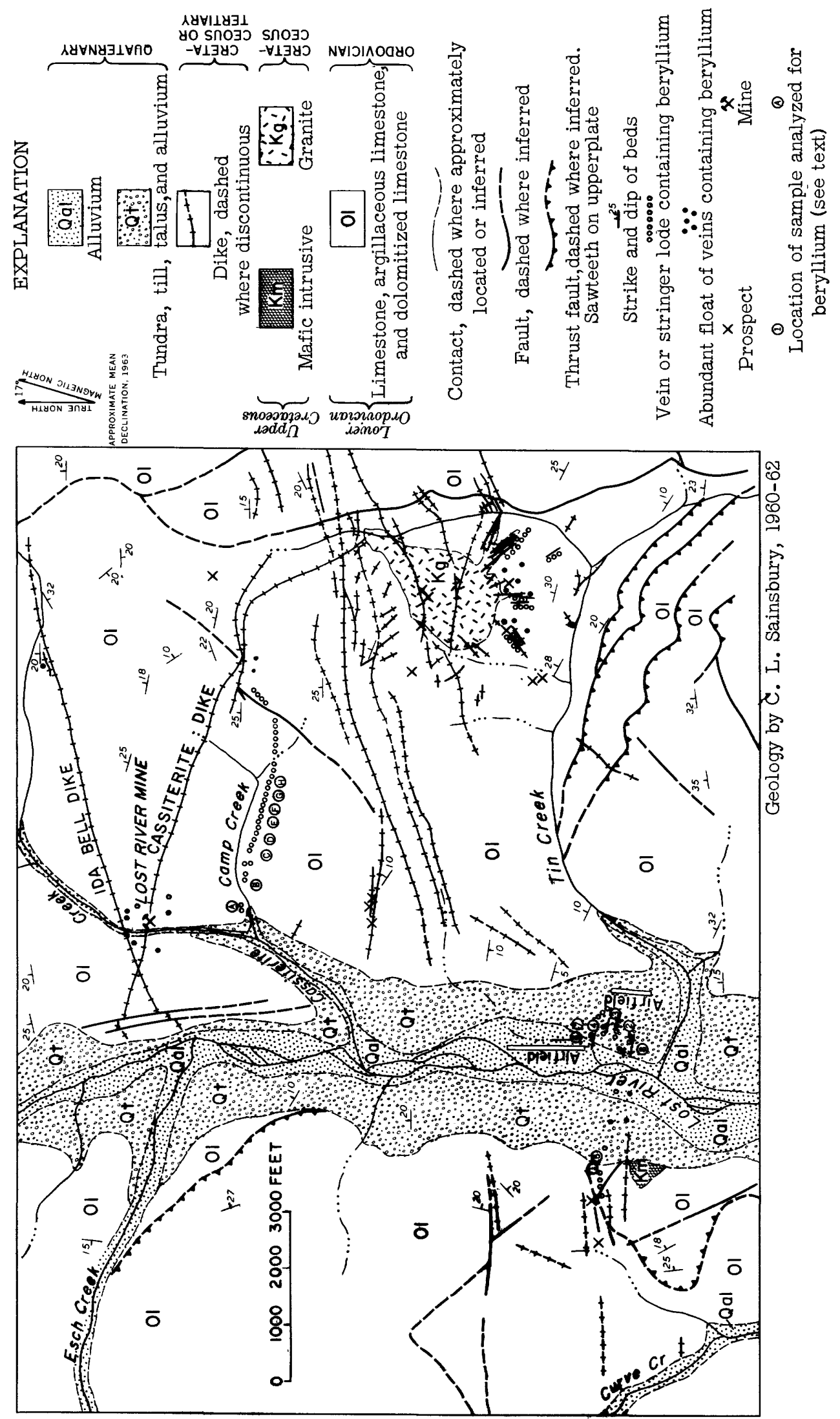


where outcrops are discontinuous and about S. $85^{\circ}$ E. for 2,000 feet, where it is traceable as a practically continuous run of heavy float which is within a few feet of its bedrock source. A continuation, or a noticeably narrower en echelon vein, crosses Camp Creek east of its main north tributary and has been traced by $\mathrm{Mr}$. Grothe (one of the owners of the Lost River mine) for at least another 2,000 feet, almost to the ridgetop between Camp Creek and Tin Creek. The weathered beryllium ore is dark purplish and stands out as a heavy float run containing thousands of tons. Ore occurs locally along cross fractures perpendicular to the main lode. Where exposed in the bed of a small gully near the eastern end of the zone of continuous float, the vein zone consists of three parallel clayfilled fractures that dip steeply south. The limestone between the fractures is partly replaced by the usual fluorite-beryllium ore. A chip sample taken across 40 feet of bedrock perpendicular to the veins contained detectable beryllium. Bulk samples of float ore and individual specimens of ore from
Camp Creek were analyzed (table 4). Most of the selected specimens contain more than the usual number of late white veinlets, which explains the fact that they contain more beryllium than the bulk samples.

The occurrence and distribution of beryllium within the immediate area of the Lost River mine are not yet well known. Numerous veinlets of fluorite, tourmaline, chrysoberyl, and diaspore, ranging in thickness from a hairline to several inches, cut the marmorized limestone. Banded fluoritetourmaline rock forms local selvages along the walls of the Cassiterite dike and also small veins parallel to the dike; samples from the selvages contain beryllium in the range 0.0015 to 0.15 percent $(0.004$ to 0.42 percent $\mathrm{BeO}$ ) (McKelvey, 1960, p. A5). Zones of iron-stained, altered, and fluoritized limestone which occur underground along the walls of the Cassiterite dike on the main-adit level contain beryllium in amounts estimated on the basis of preliminary examination with

\section{Table 4.-Beryllium and fluorine content, in percent, of ores from Canip Creek}

[Analysts: Ardith Bartel and C. L. Sainsbury, beryllium; L. F. Rader, fluorine; all of U.S. Geological Survey. Beryllium and fluorine in bulk samples determined by wet analyses by Bartel and Rader, respectively; beryllium in selected specimens determined by neutron activation by Sainsbury using laboratory instrument built by W. W. Vaughn and others. Sample type: A, bulk grab of float; B, selected specimen. For approximate location of samples see corresponding circled letters on fig. 2]

\begin{tabular}{|c|c|c|c|c|c|c|c|}
\hline Field No. & Lab. No. & Type & Location & $\mathrm{Be}$ & $\mathrm{BeO}$ & $\mathrm{F}$ & $\begin{array}{l}\mathrm{F} \text { as } \\
\mathrm{CaF}_{2} \\
\end{array}$ \\
\hline Camp Creek 1 . & 303153 & $\mathrm{~A}$ & (A) Extreme west end. & 0.25 & 0.69 & 28.9 & 57.8 \\
\hline Camp Creek 2 & 303154 & A & (B) Near west end ..... & .11 & .31 & 27.6 & 55.2 \\
\hline Camp Creek 3A-1 & 303155 & A & (C) West end continuous float. & .20 & .56 & 29.5 & 59.0 \\
\hline Camp Creek $3 \mathrm{~A}-2$ & 303156 & A & (D) West end continuous float & .24 & .67 & 27.7 & 55.4 \\
\hline Camp Creek 3B-2. & 303157 & A & (E) Center continuous float .... & .26 & .72 & 28.4 & 56.8 \\
\hline Camp Creek 3B-1. & 303158 & A & (F) Center continuous float .... & .26 & .72 & 29.0 & 58.0 \\
\hline $62-\mathrm{ASn}-791 \ldots$ & 303159 & A & (G) Distinct ore shoot.......... & .54 & 1.50 & 31.2 & 62.4 \\
\hline $62-\mathrm{ASn}-792 \ldots \ldots$ & 303160 & A & (H) East of ore shoot $\ldots . . .$. & .23 & .64 & 27.3 & 54.6 \\
\hline $62-\mathrm{ASn}-795 \ldots$ & 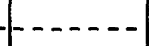 & B & Nodule, west end continuous ore & 2.16 & 6.00 & --- & - \\
\hline Assay $1 \ldots \ldots$ & $-\ldots$ & B & $\operatorname{Near}(\mathrm{A}) \ldots \ldots$ & .26 & .73 & $\ldots$ & \\
\hline Assay $2 \ldots \ldots$ & 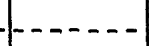 & B & 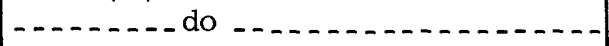 & .25 & .70 & - & \\
\hline Assay $3 \ldots \ldots$ & $-\cdots$ & B & From $(G) \ldots \ldots$ & .75 & 2.10 & $-\ldots$ & \\
\hline Assay $4 \ldots \ldots$ & $-\ldots$ & $\mathrm{B}$ & $\mid-\ldots$ do $\ldots$ d........ & .61 & 1.70 & - & \\
\hline Camp Creek select 2 & .- & B & $\ldots$ do $\ldots$ d. & .83 & 2.30 & $\ldots$ & \\
\hline Camp Creek select $3-2$ & & B & - . . . . do $\ldots$ & 1.15 & 3.20 & & \\
\hline Camp Creek select $4 \ldots$ &.- & B & $\ldots$. & .76 & 2.10 & - & \\
\hline Camp Creek select 5 & & B & $\operatorname{Near}(\mathrm{H}) \ldots$ & .65 & 1.80 & --- & \\
\hline Camp Creek select 6 . & -- & B & Near (B) ... & .35 & .97 & $\ldots$ & $1-2$ \\
\hline Camp Creek select 7 . & $-\cdots--$ & B & $\operatorname{Near}(A) \ldots \ldots$ & .36 & 1.02 & - & \\
\hline
\end{tabular}


the beryllium detector at as much as 0.5 percent $\mathrm{BeO}$. In contrast to the fluorite-beryllium veins elsewhere in the district, this banded fluorite-tourmaline rock locally contains as much as 3.35 percent tin, most of which is in cassiterite. The distribution of these fluoritized rocks within the mine is shown on detailed geologic maps prepared in 1953-55 (Sainsbury, in press).

During 1960 and 1961, the U.S. Bureau of Mines drilled several dozen percussion drill holes in marmorized limestone along Cassiterite Creek to test the overall tenor of the limestone, and a report on this work is being prepared (J. A. Herdlick, oral communication, 1962). Complete evaluation of the beryllium potential of the Lost River mine will require additional detailed work.

\section{LOST RIVER VAI,LEY}

The known beryllium lodes in what is here termed "Lost River valley" form an eastwardtrending belt of en echelon replacement veins which cross Lost River about $1 \frac{1}{2}$ miles below the Lost River mine (fig. 2). The deposits were discovered in late August 1962 and have not yet been mapped in detail. The ore is the usual banded fluorite-diaspore-chrysoberyl variety. Vein material has been found in place and as float in a zone approximately
1,000 feet wide and 4,200 feet long. The known mineralized area starts near an old airstrip on the low hill between Lost River and Tin Creek and continues west at least as far as the Bessie and Mabel prospect, which lies on the ridge between Lost River and Curve Creek. The geology in the vicinity of this prospect was shown first by Steidtmann and Cathcart (1922, p. 78). East of the alluvium in Lost River, several replacement veins as much as several hundred feet long are marked by continuous runs of float in the thin mantle of frost-riven limestone and tundra which covers bedrock. These veins are parallel to discontinuous mafic dikes which weather dark brown. Locally, replacement veins lie along dike walls, but most of the veins are along fractures unoccupied by dikes. A single bulldozer trench dug by $\mathrm{Mr}$. Grothe across one of the float zones exposed banded fluorite rock about 3 feet thick.

Ore fragments as much as a foot across have been brought to the surface in frost boils in the alluvium of Lost River, and float ore occurs in distinct linear runs across the wide tundra-covered bench west of the river to the point where bedrock appears. Here banded and veined fluorite-beryllium rock crops out as lenticular masses up to 12 feet wide and 100 feet long, and a combined replacement vein and stringer lode continues

Table 5.-Berylliuni and fluorine content, in percent, of ores from Lost River valley

[Analysts: Ardith Bartel and C. L. Sainsbury, beryllium; L. F. Rader, fluorine, U.S. Geological Survey. Beryllium and fluorine in bulk samples determined by wet analyses by Bartel and Rader, respectively; beryllium in selected specimens determined by neutron activation by Sainsbury using laboratory instrument built by W. W. Vaughn and others. Sample type: A, random bulk sample of float fluorite rock from one particular vein or outcrop; $B$, single specimen float from base of outcrop or in alluvium]

\begin{tabular}{|c|c|c|c|c|c|c|c|c|}
\hline \multirow{2}{*}{ Field No. } & \multirow{2}{*}{ Lab. No. } & \multirow{2}{*}{ Type } & \multirow{2}{*}{\begin{tabular}{|c|} 
Circled \\
no. \\
fig. 2
\end{tabular}} & Location & \multirow{2}{*}{$\mathrm{Be}$} & \multirow{2}{*}{$\mathrm{BeO}$} & \multirow{2}{*}{$\mathrm{F}$} & \multirow{2}{*}{$\begin{array}{l}\mathrm{F} \text { as } \\
\mathrm{CaF}_{2}\end{array}$} \\
\hline & & & & Description & & & & \\
\hline Bessie-Mabel_...... & 303149 & A & 15 & $\begin{array}{l}\text { South of east dump, Bessie and } \\
\text { Mabel. }\end{array}$ & 0.4 & 0.389 & 28.6 & 58.8 \\
\hline East Lost River 1 _.- & 303150 & A & 2 & East of road on bench & .25 & .694 & 24.4 & 50.1 \\
\hline East Lost River 2 .. & 303151 & A & 3 & East of road on bench, 2 nd vein.-- & .15 & .416 & 23.0 & 47.3 \\
\hline East Lost River 3 .. & 303152 & A & 4 & East of road on bench, 3 rd vein_- & .17 & .472 & 27.1 & 55.7 \\
\hline B. M. 1 & $-\ldots$ & B & 5 & $\begin{array}{l}\text { Putcrop south of Bessie and } \\
\text { Mabel. }\end{array}$ & .23 & .64 & & \\
\hline LRV 01 & $\ldots$ & B & 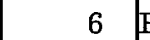 & Frost boils along road & .35 & .97 & & \\
\hline LRV $03 \ldots$ & 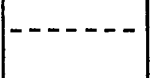 & B & 7 & $\begin{array}{l}\text { Frost boil } 100 \text { feet east of } \\
\text { road. }\end{array}$ & .70 & 1.95 & & \\
\hline LRV $04 \ldots$ & $\ldots$ & B & 8 & $\begin{array}{l}\text { From float run, bench, east of } \\
\text { road. }\end{array}$ & .27 & .76 & & \\
\hline
\end{tabular}


for several hundred feet along a fracture zone trending about west. Several brown-weathering dikes follow some of these fractures. The western continuation of ore has not been delimited.

The ore near the Bessie and Mabel prospect in in thin-bedded medium-gray to darkgray dolomitic limestone, probably of latest Early Ordovician age, which is overlain to the west and north by argillaceous limestone believed to be of early Early Ordovician age. These relations suggest that the dolomitic limestone is part of a thrust sheet (fig. 2). A small mafic pluton intrudes the dark dolomitic limestone about 100 yards south of the ore outcrops.

Analyses of bulk samples of ore and of selected specimens of ore from outcrops near the Bessie and Mabel prospect and from linear float runs east of Lost River are given in table 5.

\section{RAPID RIVER}

The beryllium deposits in Rapid River lie $4 \frac{1}{2}$ miles by air S. $65^{\circ} \mathrm{W}$. from Lost River mine (fig. 1). They consist of veins and pipes of fluorite-beryllium ore and of stringer lodes or stockworks in fractured argillaceous limestone. The general geology is shown in figure 3 . The deposits are alined in a zone about 4,400 feet long and 1,000 feet wide trending $\mathrm{N} .85^{\circ} \mathrm{E}$. across Rapid River, a tributary of Lost River. The ores are similar to those previously described, although tourmaline is more common in the Rapid River ores than elsewhere.

The best deposits exposed lie east of Rapid River on a wide bench covered by a thin veneer of frost-riven limestone and tundra. Within this area, which is about 1,200 feet long and 800 feet wide, ore occurs as replacement veins as much as 300 feet long and as elliptical pipes as much as 30 feet long. These lie within areas containing abundant float fragments of ore that show the underlying limestone contains veins and veinlets as much as 1 foot thick. The more continuous veins, which can be traced by surface float, strike parallel to the main fault. Numerous preore lenticular dikes of quartz diabase intruded fractures nearly parallel to the veins. Near the dikes and veins, the argillaceous limestone has been completely brecciated and dolomitized. About 1,300 feet south of the best ore, a swarm of larger and more continuous dikes, including quartz diabase and rhyolite porphyry, strikes subparallel to the ore-bearing fault and cuts a thrust plate exposed on the hill to the east. Only small amounts of fluorite-beryllium ore have been found along these dikes.

Both the fluorite-beryllium veinlets and the quartz diabase dikes continue west of Rapid River into an area covered more deeply by tundra and alluvium where only a little ore crops out, commonly as selvages along dike walls. This area lies just north of a thick dolomite breccia, which may mark the continuation of a major fault to the west that dips south at a low angle, outside the area of figure 3. Dikes of quartz diabase cut the dolomite breccia, but no fluorite-beryllium ore is known to be associated with them. A sample of stream sediments from a tributary entering Rapid River from the west, just south of the area shown in figure 3 , contains $15 \mathrm{ppm}$ (parts per million) beryllium.

Small veins and fragments of fine-grained gray quartz containing minor fluorite and calcite are common in the argillaceous limestone north of the beryllium-bearing veins, and the fault east of the main ore zone is filled with quartz. No quartz occurs in the fluorite ores.

Samples from the Rapid River area gave the results shown in table 6 .

\section{TIN CREEK}

The beryllium deposits in Tin Creek are about 1-3/4 miles southeast of the Lost River mine. Figure 1 shows the location, and figures 2 and 4 show the geology of the area. Two distinct types of deposits are present, veins and veinlets of the usual fluorite-diasporechrysoberyl-mica type common elsewhere, and beryllium-bearing skarn (tactite) at the margins of a medium-grained biotite granite that intrudes limestone. The fluorite-beryllium ores at Tin Creek locally contain considerable manganese and in general more mica and sulfide minerals than they do elsewhere. Weathering of the sulfide minerals in some of the veins has produced a porous ore stained heavily with limonite. Samples of this type of ore are referred to as "oxidized ore" in table 7. The skarn ores have been described by Knopf (1906) and, inasmuch as they are of relatively low beryllium content, they 

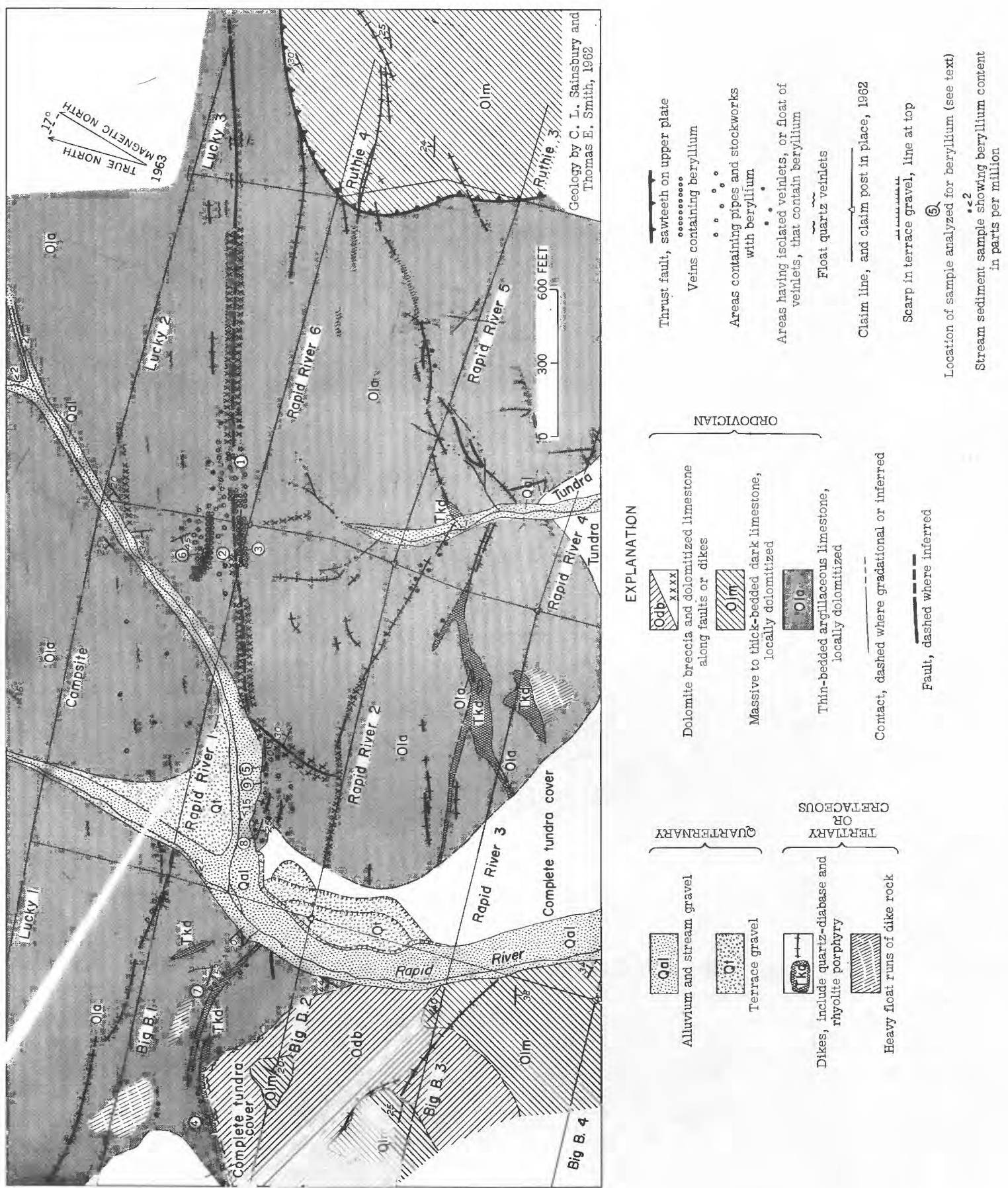

贾 
Toble 6.-Beryllium and fluorine content, in percent, of ores from Rapid River

[Analysts: Ardith Bartel and C. L. Sainsbury, beryllium; L. F. Rader, fluorine, U.S. Geological Survey. Beryllium and fluorine in RR-1 and RR-2 determined by wet analyses by Bartel and Rader, respectively; beryllium in remaining samples determined by neutron activation by Sainsbury, using laboratory instrument built by W. W. Vaughn and others. Sample type: A, random bulk of float fluorite rock; B, single specimen of float or outcrop of single vein; C, bulk of alluvium in main ore zone]

\begin{tabular}{|c|c|c|c|c|c|c|c|c|}
\hline \multirow{2}{*}{ Field No. } & \multirow{2}{*}{ Lab. No. } & \multirow{2}{*}{ Type } & \multirow{2}{*}{$\begin{array}{c}\text { Circled } \\
\text { no., } \\
\text { fig. } 3\end{array}$} & Location & \multirow{2}{*}{$\mathrm{Be}$} & \multirow{2}{*}{$\mathrm{BeO}$} & \multirow{2}{*}{$\mathrm{F}$} & \multirow{2}{*}{$\begin{array}{l}\mathrm{F} \text { as } \\
\mathrm{CaF}\end{array}$} \\
\hline & & & & Description & & & & \\
\hline$R-1$ & 303147 & A & & Main ore area, east bench...... & 0.24 & 0.666 & 27.6 & 56.7 \\
\hline RR-2.. & 303148 & A & & - & .24 & .666 & 27.5 & 56.5 \\
\hline $62-\mathrm{ASn}_{-}-\mathrm{B}_{-}$ & & $\mathrm{C}$ & -- & $\mid$ & .05 & .15 & & \\
\hline 32-ASn-C- & & A & 1 & $\begin{array}{l}\text { Vein float, main ore area, east } \\
\text { end. }\end{array}$ & .14 & .38 & & \\
\hline $32-\mathrm{ASn}-\mathrm{E}$ & & $\mathrm{C}$ & 2 & $\begin{array}{l}\text { Alluvium, main ore area, east } \\
\text { end. }\end{array}$ & .09 & .26 & & \\
\hline $2-\mathrm{ASn}_{-}-\mathrm{F}_{-}$ & & A & 3 & $\begin{array}{l}\text { Single vein, north center main } \\
\text { ore area. }\end{array}$ & .38 & 1.05 & & \\
\hline $\mathrm{Sn}-$ & & A & 4 & Dike walls, west end ore zone _- & .30 & .82 & - & \\
\hline 2-ASn-RR8 - & & B & 5 & $\begin{array}{l}\text { Fluoritized limestone from dike } \\
\text { wall, east tributary of Rapid } \\
\text { River. }\end{array}$ & .05 & .15 & -. & \\
\hline 2-ASn-1 & & A & 6 & 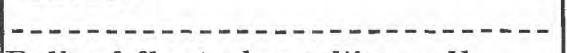 & .26 & .72 & & \\
\hline 32-ASn & & A & 7 & $\begin{array}{l}\text { Bulk of float along dike wall, } \\
\text { west of Rapid River. }\end{array}$ & .18 & .50 & & \\
\hline 62-ASn-RR13A & & A & 8 & $\begin{array}{l}\text { Veinlets, south edge of creek } \\
\text { bed of east tributary of Rapid } \\
\text { River. }\end{array}$ & .12 & .32 & $\ldots$ & \\
\hline 62-ASn-RR15 - & & B & 9 & $\begin{array}{l}\text { Pinkish fluorite veinlet } 4 \text {-in. } \\
\text { wide, south edge of creek bed } \\
\text { of east tributary of Rapid } \\
\text { River. }\end{array}$ & .18 & .50 & $\ldots$ & \\
\hline
\end{tabular}

are not here considered as a potential ore of beryllium. The better deposits are replacement veins which formed in fractures which occur radially around the south margin of the granite. Rhyolite porphyry and porphyry dikes containing conspicuous feldspar phenocrysts intruded the granite and country rock along some of the radial fractures prior to the formation of the fluorite-beryllium veins. Dikes were injected also along numerous faults of the regional systems striking N. $85^{\circ}$ E. and N. $40-50^{\circ} \mathrm{W}$. Very little fluorite-beryllium ore has been found along these dikes, whereas many of the veins are localized at margins of the dikes which intruded the radial fractures on the south margin of the granite (fig. 4).

The most promising vein can be traced for about 700 feet and reaches a maximum thick- ness of 8 feet. Other veins, most of which are recognized only by linear runs of float in frost-riven bedrock, can be traced for several hundred feet but are of unknown thickness. Smaller veinlets as much as 6 inches thick ramify in the limestone on the south margin of the granite, where they give rise to abundant float. A few of the larger veins continue into the granite for short distances.

Base-metal veins near the granite have been described by Knopf (1906) and by Steidt mann and Cathcart (1922), as were in the tin deposits, and are not discussed here. With respect to exploration in other areas, it is important to point out that most of the fluorite-beryllium veins at Tin Creek lie well away from the granite beyond the berylliumbearing skarns and do not coincide with the tin deposits. This physical separation between 

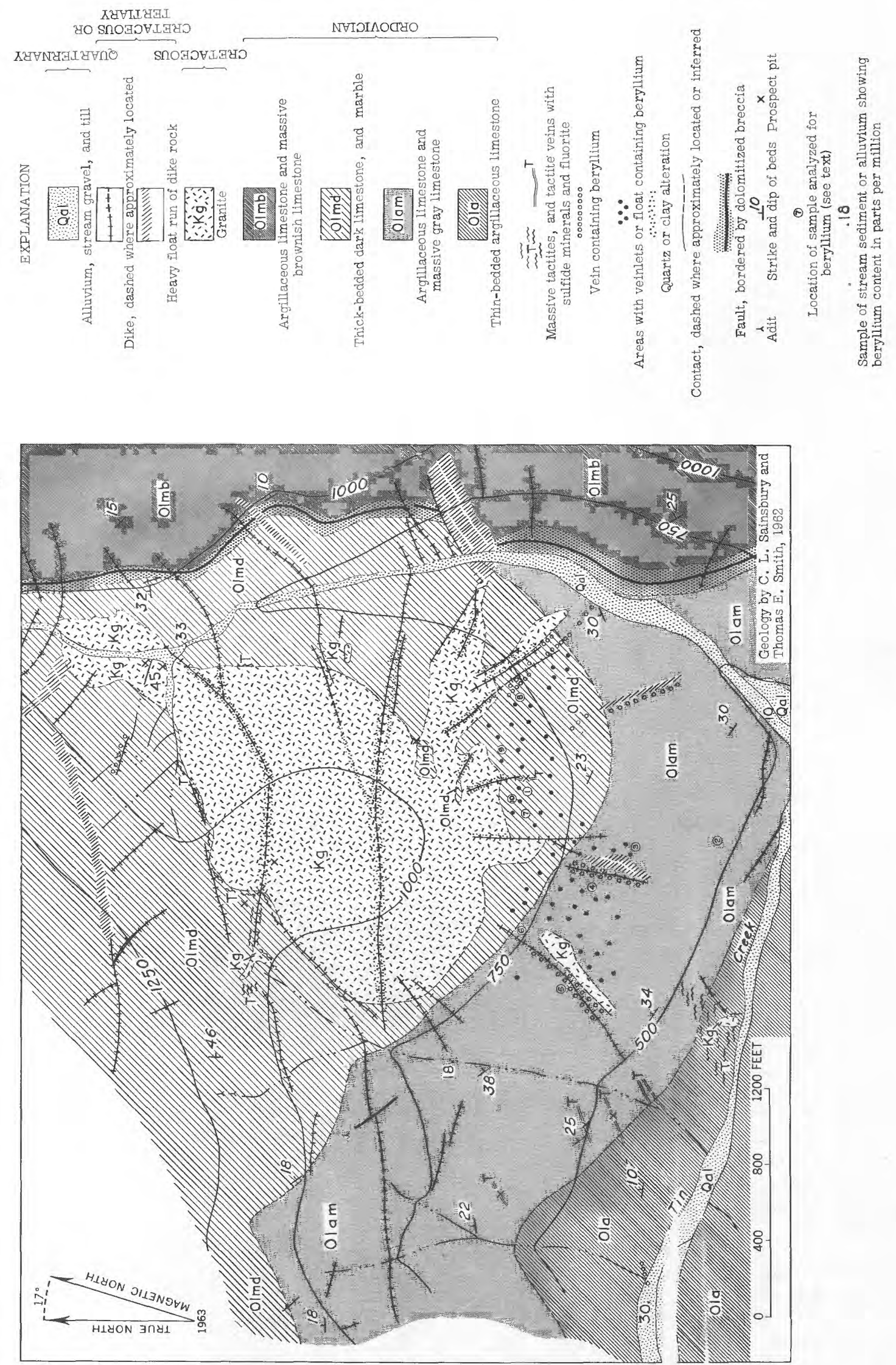
Table 7.-Beryllium content of ores, in percent, from Tin Creek

[Analyst: C. L. Sainsbury, U.S. Geological Survey. Beryllium determined by neutron activation using laboratory instrument built by W. W. Vaughn and others. Sample type: A, bulk grab of float or outcrop; B, single specimen of vein float]

\begin{tabular}{|c|c|c|c|c|c|}
\hline \multirow{2}{*}{ Field No. } & \multirow{2}{*}{ Type } & \multirow{2}{*}{$\begin{array}{c}\text { Circled } \\
\text { no., } \\
\text { fig. } 4\end{array}$} & Location & \multirow{2}{*}{$\mathrm{Be}$} & \multirow{2}{*}{$\mathrm{BeO}$} \\
\hline & & & Description & & \\
\hline 2-ASn-TC 29_ & A & 1 & Oxidized ore & 0.17 & 0.47 \\
\hline 62-Asn-TC $33 \ldots$ & A & 2 & Veinlets in limestone & .14 & .40 \\
\hline $62-$ Asn-TC $35 \ldots$ & A & 3 & Oxidized ore & .20 & .56 \\
\hline $62-\mathrm{ASn}-\mathrm{TC} 36 \ldots$ & A & 4 & (1) & .05 & .13 \\
\hline $62-\mathrm{ASn}-\mathrm{TC} 38 \ldots$ & A & 5 & Fluorite-beryllium vein & .27 & .76 \\
\hline $62-\mathrm{ASn}-\mathrm{TC} 40 \ldots$ & A & 6 & $\begin{array}{l}\text { Fluorite-beryllium vein, southwest side of } \\
\text { granite. }\end{array}$ & .35 & .98 \\
\hline 62-ASn-TC 41 & A & 7 & $\begin{array}{l}\text { Leached, porous ore from vein near south } \\
\text { margin, of granite. }\end{array}$ & .31 & .85 \\
\hline 62-ASn-TC 42 & A & 8 & $\begin{array}{l}\text { Northwest end of most continuous vein, southeast } \\
\text { side of granite. }\end{array}$ & .21 & .58 \\
\hline 62-ASn-TC 01 & B & 9 & 4 -in. vein, near south margin of granite & .40 & 1.11 \\
\hline 62-ASn-TC $02 \ldots$ & B & 10 & $6-$ in. vein, south margin of granite & .31 & .85 \\
\hline
\end{tabular}

the ores of tin and tungsten, and of beryllium, is also noted at Camp Creek and in Lost River valley.

Analyses of fluorite-beryllium ore from Tin Creek are reported in table 7.

\section{AREAS FAVORABLE FOR PROSPECTING}

Other areas on the western Seward Peninsula that are considered favorable ground for prospecting are shown on figure 1 and discussed below. Geochemical reconnaissance has already been done in some of these, and results have been encouraging. In other areas where geologic conditions are considered favorable, no geochemical reconnais sance has yet been carried out.

\section{LOST RIVER-BROOKS MOUNTAIN AREA}

The results of sampling stream sediments and slope wash from the drainage basin of Lost River are shown on figure 5. Beryllium in amounts as high or higher than that found in Tin Creek occurs in slope wash from the south margin of the granite of Brooks Mountain. This may be contained in disintegrating idocrase which often contains a high percentage of beryllium (Warner and others, 1959, p. 17) and which is widespread in the contact rocks around the granite. However, the be ryllium may have been derived from deposits, partly exposed in several prospects at the

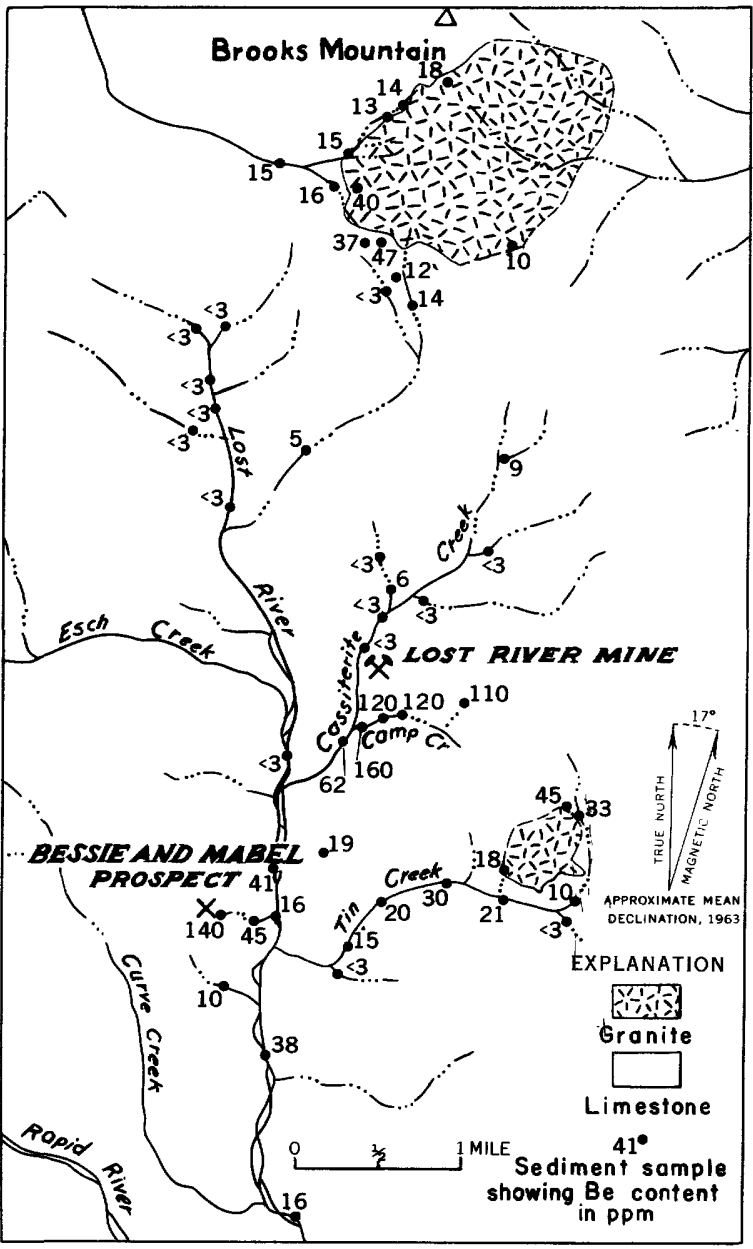

Figure 5. -Map showing location and beryllium content of sediment samples, Lost River area, Seward Peninsula, Alaska. 
margin of the granite, that contain abundant fluorite as well as sulfide minerals. Several northwest-striking veins cut the limestone on the ridge northwest of these prospects. The lodes near the south margin of the granite of Brooks Mountain have been described in some detail by West and White (1952). The similarity to the Tin Creek area is striking.

Where the Ida Bell dike of the Lost River mine crosses the south headwaters of Cassiterite Creek (fig. 2), T. E. Smith obtained float pieces of fluorite-beryllium ore that contain 0.58 percent $\mathrm{BeO}$. This area should be examined in detail.

\section{KING RIVER}

In the second small tributary entering King River (fig. 1) from the east, a small pluton similar to that south of the Bessie and Mabel prospect intrudes argillaceous limestone. Brown-weathering dikes extend westward and eastward from this pluton. The area has not been prospected for beryllium deposits, but the similarity to the area herein called Lost River valley suggests that it should be pros pected.

\section{AREA EAST OF TIN CREEK}

Faults of the persistent system striking eastward from Rapid River to Tin Creek continue at least into the headwaters of the next streams about 2 miles east of Tin Creek. Brown-weathering dikes also continue east of Tin Creek, and the area should be prospected.

\section{EAR MOUNTAIN}

At Ear Mountain, 41 miles N. $40^{\circ} \mathrm{E}$. of the Lost River mine (fig. 1), a porphyritic biotite granite that intrudes schistose limestone of the Port Clarence is accompanied by tin, fluorite, and sulfides. The general geology, taken from a map prepared by P. L. Killeen (1945), is shown on figure 6 . The beryllium content of stream sediments and alluvium collected

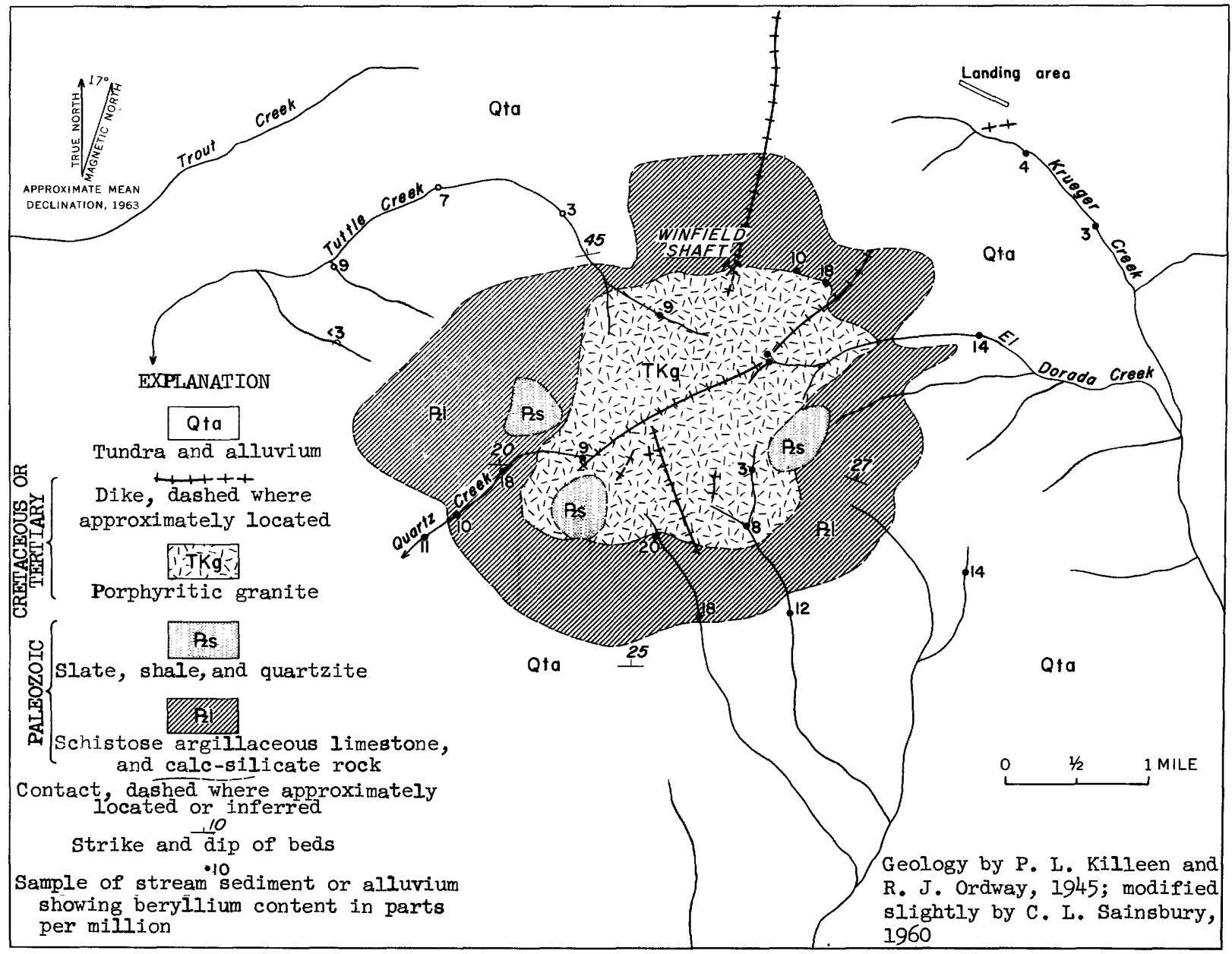

Figure 6. -Geologic map of Ear Mountain, Seward Peninsula, Alaska. 


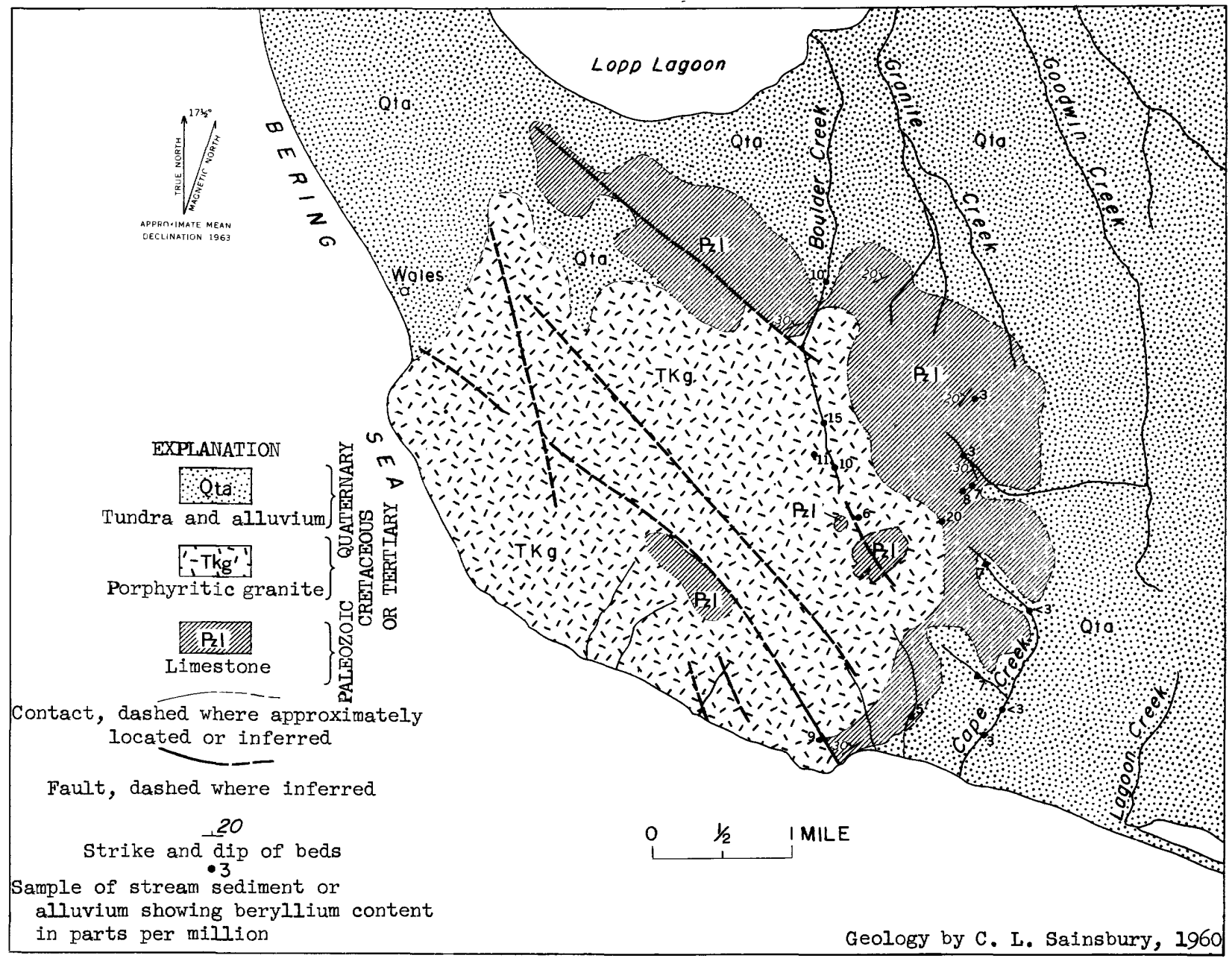

Figure 7. - Geologic map of Cape Mountain, Seward Peninsula, Alaska.

by the writer in 1960 are also plotted: they show a distinct geochemical anornaly around the granite. Mafic dikes similar to those associated with beryllium deposits in Lost River valley cut the granite and surrounding limestone as at Tin Creek. Rock samples randomly collected from metasornatized limestone near the Winfield shaft contain as much as 380 ppm of berylliurn. The limestone surrounding Ear Mountain should be prospected in detail, even though good exposures are limited to a zone about half a mile wide around the granite. Beyond this, tundra covers most of the bedrock, and geochemical methods would be required.

\section{CAPE MOUNTAIN}

A porphyritic biotite granite intrudes limestone at Cape Mountain at the western tip of the Seward Peninsula (figs. 1 and 7). Lode and placer tin deposits are associated with the intrusions. The granite and surrounding limestone are cut by fractures, many of which are intruded by dikes (Steidtmann and Cathcart, 1922). Geochemical reconnaissance shows anomalous amounts of beryllium, which are not, however, as great as those at Ear Mountain and Lost River. Prospecting will be hampered by the tundra which covers most of the area surrounding Cape Mountain on the east and north. The geochemical data are insufficient to prove or disprove the existence of beryllium deposits, but additional prospecting is warranted.

\section{Potato MOUNTAIN}

At Potato Mountain (fig. 1), the slate is cut by numerous quartz veins containing cassiterite and by several types of dikes (Steidtmann and Cathcart, 1922). More than 2,000 tons of placer tin has been recovered from creeks draining Potato Mountain, and recent 


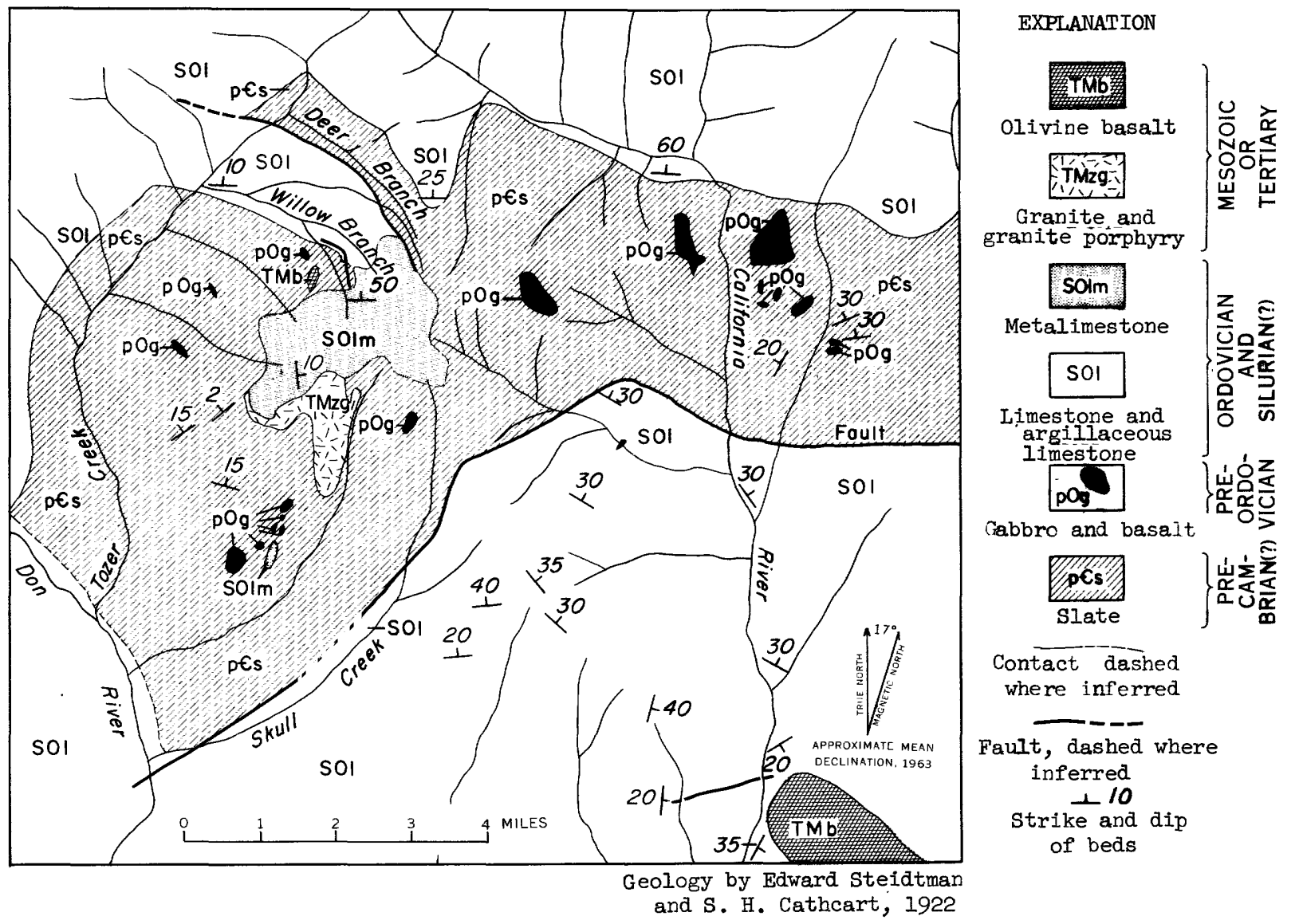

Figure 8. -Geologic map of Black Mountain area, Seward Peninsula, Alaska.

diamond drilling by the U.S. Bureau of Mines has disclosed kaolinized veins containing tourmaline and cassiterite (J.J. Mulligan, oral communication, 1961). Although beryllium may be associated with the tin lodes, the bedrock is slate. The presence of the slate bedrock is considered an unfavorable factor because fluorine-bearing solutions would not react so readily with slate as with limestone, and beryllium lodes, if they exist, would likely be narrow. Prospecting would be difficult because of the almost continuous tundra which mantles the entire area. However, the area may warrant geochemical exploration.

\section{BLACK MOUNTAIN}

At Black Mountain, some 14 miles due east of Lost River (fig. 1), a biotite granite pluton intrudes slate and the Port Clarence Limestone. The general geology of the area is described in some detail by Steidtmann and Cathcart (1922), whose geologic map is reproduced in this report as figure 8 . Although no tin, boron, or fluorine minerals are known around the granite, skarn and veins containing pyrite and arsenopyrite do occur. Several sets of faults cut the limestone, and some are intruded by dikes. Beryllium could be present.

\section{SUGGESTIONS FOR PROSPECTING}

These beryllium ores are not of a common, well-known type and can easily be overlooked. It seems worthwhile, therefore, to make available to future searchers experience gained by the writer over several seasons.

It should be emphasized that the fluorite beryllium rock can be recognized visually, although some practice is needed if it is in dolomite. All the deposits discussed in this report were discovered in this manner. The chief value of the beryllium detector is to confirm the beryllium content of the ores and to trace ore zones through areas covered by tundra. The detector proves valuable in tracing ore into dolomitized limestone but is no substitute for careful prospecting. A 
prospector who has examined any of the lodes discussed herein to familiarize himself with the ore has a good chance of recognizing other lodes that may crop out elsewhere.

Geochemical reconnaissance by use of stream sediments is of value for outlining broad areas that contain beryllium lodes and is considered to be the best method available for prospecting in areas not covered already by such reconnaissance. In our work, we took a bulk sample of the fine-grained sediment found in the lee of boulders in most streams. Most of this sediment passed a 40-mesh screen. If it proved impractical to secure such sediment, larger amounts of coarser material were screened to obtain sufficient material. On hillslopes without streams, sediments in rivulets or water-sorted alluvium were sampled. A dependable method using an ultraviolet light and common chemicals to determine trace amounts of beryllium has been developed by the Geological Survey (Patten and Ward, 1962) and can be applied in the field.

The background content of beryllium in sediments from the limestone areas was determined to be less than $2 \mathrm{ppm}$. Values be tween 3 and $10 \mathrm{ppm}$ are definitely anomalous, and experience shows that where values are consistently greater than $15 \mathrm{ppm}$, megascopic amounts of fluorite-beryllium vein material are present either in the stream bed or in bedrock nearby. If values reach $30 \mathrm{ppm}$ in areas without noticeable skarn in bedrock or in the stream bed, veins as large as those in Tin Creek or Rapid River probably exist within a few hundred feet; if values are found in excess of $100 \mathrm{ppm}$, large quantities of ore should be found within a few dozen feet either in place or as numerous boulders in the creek bed, as is true in Camp Creek.

In prospecting new areas, particular attention should be paid to the limestone surrounding granites and to limestone areas containing dikes that weather dark brown. Present experience indicates that areas having numerous short dikes alined along the N. 70-85 E. fault system are more likely to contain fluorite-beryllium deposits than areas containing large and continuous dikes of rhyolite. The vicinity of dark dikes is considered more favorable than that of rhyolite and rhyolite porphyry, which are usually more closely related to tin deposits.
In areas containing tin lodes, as at Ear Mountain and Cape Mountain, attention should be focused on surrounding areas, particularly if dikes or fractures can be found nearby. Above all, any distinctly dark colored area in the usually gray or white limestone should be examined, especially if the dark area has a tinge of purple. Faint linear trends in thin alluvium on upland areas should be examined in detail.

Most of the ore is noticeably heavy because of its high fluorite content. It is more resistant to frost breaking than most of the argillaceous limestone, and blocks as much as 6 inches in diameter can be found in float runs on gentle slopes where the associated limestone fragments seldom exceed an inch or two. In places the late fluorite veins cutting some of the ore have an unmistakable light bluish to purple coloration. Most of the fluorite in the ores, however, is fine-grained and white to grayish, and cannot be recognized easily.

Because all the promising lodes found to date are in limestone areas, the broad expanses of limestone in the York Mountains and to the east and north of Black Mountain should be prospected before attention is paid to the slate outside those areas specifically discussed in this report.

The fact that all the known lodes discussed herein consist of the usual fluorite-diasporechrysoberyl type does not preclude the possibility that other types may also exist.

\section{SELECTED BIBLIOGRAPHY}

Brooks, A. H., 1902, Placer gold mining in Alaska in 1902 , in Contributions to economic geology: U.S. Geol. Survey Bull. 213, p. $41-48$.

Collier, A. J., 1902, A reconnaissance of the northwestern portion of Seward Peninsula, Alaska: U.S. Geol. Survey Prof. Paper 2, $70 \mathrm{p}$.

Heide, H. E., 1946, Investigation of the Lost River tin deposit, Seward Peninsula, Alaska. U.S. Bur. Mines Rept. Inv. 3902, 57 p.

Heide, H. E., and Rutledge, F. A., 1949, Investigation of Potato Mountain tin placer deposits, Seward Peninsula, Northwestern Alaska: U.S. Bur. Mines Rept. Inv. 4418, $21 \mathrm{p}$. 
Heide, H. E., Wright, Wilford, S., and Sanford, Robert S., 1946, Exploration of Cape Mountain lode tin deposits, Seward Peninsula, Alaska: U.S. Bur. Mines Rept. Inv. 3978, $16 \mathrm{p}$.

Killeen, P. L., and Ordway, R. J., 1945, Radioactivity investigations at Ear Mountain, Seward Peninsula, Alaska: U.S. Geol. Survey Bull.1024-C, p. 59-94.

Knopf, Adolph, 1908, Geology of the Seward Peninsula tin deposits: U.S. Geol. Survey Bull. 358, $71 \mathrm{p}$.

Lorain, S. H. and others, 1958, Lode tin mining at Lost River, Seward Peninsula, Alaska: U.S. Bur. Mines Inf. Circ. 7871, 76 p.

McKelvey, V. E., compiler, 1960, Geological Survey research 1960, Synopsis of geologic results: U.S. Geol. Survey Prof. Paper 400-A, $136 \mathrm{p}$.

Mulligan, J. J., 1959, Sampling stream gravels fortin near York, Seward Peninsula, Alaska: U.S. Bur. Mines Rept. Inv. 5520, 25 p. 1959, Tin place $r$ and lode investigations

Ear Mountain area, Seward Peninsula, Alaska: U.S. Bur. Mines Rept. Inv. 5493, $53 \mathrm{p}$.

Mulligan, J. J., and Thorne, Robert L., 1959, Tin placer sampling methods and results, Cape Mountain district, Seward Peninsula, Alaska: U.S. Bur. Mines Inf. Circ. 7878, $69 \mathrm{p}$.

Patten, L. E., and Ward, F. N., 1962, Geochemical field method for beryllium prospecting,
Short Papers in geology and hydrology: U.S. Geol. Survey Prof. Paper 450-C, p. C103-C104.

Sainsbury, C. L., 1960, Metallization and postmineral hypogene argillization, Lost River tin mine, Alaska: Econ. Geology v. 55, no. 7, p. 1478-1506. 1962, A new occurrence of beryllium minerals on the Seward Peninsula, Alaska: U.S. Geol. Survey open-file report.

Sainsbury, C. L., Helz, Arvin W., Annell, Charles, S., and Westley, Harold, 1961, Beryllium in stream sediments from the tin-tungsten provinces of the Seward $\mathbf{P e}-$ ninsula, Alaska, in Short papers in the geologic and hydrologic sciences: U.S. Geol. Survey Prof. Paper 424-C, p. C16-C17.

Sainsbury, C. L., 1963, Geology of the Lost River mine area, Seward Peninsula, Alas ka: U.S. Geol. Survey Bull. 1129 (in press).

Steidtmann, Edward, and Cathcart, S. H., 1922, Geology of the York tin deposits, Alaska: U.S. Geol. Survey Bull. 733, 130 p.

Warner, L. A., Holser, W. T., Wilmarth, V. R., and Cameron, E. N., 1959, Occurrence cf nonpegmatite beryllium in the United States: U.S. Geol. Survey Prof. Paper 318, 198 p.

West, W. S., and White, M. G., 1952, An occurrence of zuenerite at Brooks Mountain, Seward Peninsula, Alaska: U.S. Geol. Sur vey Circ. 214,7 p. 